NBER WORKING PAPER SERIES

\title{
BANK INTEGRATION AND
}

STATE BUSINESS CYCLES

Donald P. Morgan

Bertrand Rime

Philip E. Strahan

Working Paper 9704

http://www.nber.org/papers/w9704

\section{NATIONAL BUREAU OF ECONOMIC RESEARCH 1050 Massachusetts Avenue \\ Cambridge, MA 02138}

May 2003

The views expressed are those of the authors and do not necessarily reflect the position of the Swiss National Bank, the Federal Reserve Bank of New York, or the Federal Reserve System. We thank Jean Tirole for his comments and Paul Edelstein and Shana Wang for their research assistance. The views expressed herein are those of the authors and not necessarily those of the National Bureau of Economic Research.

C2003 by Philip E. Strahan, Donald P. Morgan, and Bertrand Rime. All rights reserved. Short sections of text not to exceed two paragraphs, may be quoted without explicit permission provided that full credit including Cnotice, is given to the source. 
Bank Integration and State Business Cycles

Donald P. Morgan, Bertrand Rime, and Philip E. Strahan

NBER Working Paper No. 9704

May 2003

JEL No. G2

\section{$\underline{\text { ABSTRACT }}$}

We investigate how the better integration of U.S. banks across states has affected economic volatility within states. In theory, the link between bank integration and volatility is ambiguous; integration tends to dampen the impact of bank capital shocks on state activity, but it amplifies the impact of firm collateral shocks. Empirically, the net effect has been stabilizing as year-to-year fluctuations in employment growth within states fall as that state's banks become better integrated (via holding companies) with banks in other states. The magnitudes are large, and the effects are most pronounced in states with relatively undiversified economies. Consistent with our model, we find the link between economic growth and bank capital within a state weakens with integration, whereas the link between growth and housing prices (a possible proxy for firm capital) tends to increase.

Donald Morgan

Research Department

Federal Reserve Bank of New York

33 Liberty Street

New York, NY 10045

don.morgan@ny.frb.org

Philip Strahan

Carroll School of Management

Boston College

140 Commonwealth Avenue

Chestnut Hill, MA 02467

and NBER

philip.strahan@bc.edu
Bertrand Rime

Swiss National Bank

Börsenstr. 15, Postfach

8022 Zürich

rime@snb.ch 


\section{Introduction}

The United States once had essentially 50 little banking systems, one per state. States themselves limited geographic expansion with laws blocking entry by banks headquartered in other states. Once states began opening their borders to out-of-state banks in the late 1970 s, our many systems began rapidly converging toward a more national banking system dominated by very large holding companies operating banks in many states (Map). U.S. banks are not just getting bigger as they consolidate; they are also getting wider. This other dimension of bank consolidation—geographic integration—-has been largely neglected by researchers, hence our paper.

Under the segregated regime, the fate of a state and its banks were closely tied; as went the states, so went the banks. Farm price deflation in the early 1980s bankrupted many farmers and many farm banks. Falling oil prices in the mid-80s wiped out a lot of Texans and a lot Texas banks. While the price drops probably precipitated these crises, our maintained premise is that the associated loss of collateral by firms and the loss of capital at banks prolonged and deepened crises, and that integration--allowing banks to enter and exit states--should alter the feedback between real and financial shocks.

As a starting point for thinking about those effects, we work through an extended version of the banking model in Holmstrom and Tirole (HT,1997). Bankers in that model both prevent moral hazard — by monitoring firms — and they commit moral hazard — by neglecting to monitor. Because of these hazards or frictions, equilibrium investment in an economy depends on the level of firm collateral and bank capital; these seemingly backward-looking variables give firms and bankers a stake in future investment outcomes, and that keeps them honest. Negative shocks to either firm collateral or bank 
capital cause investment to contract. We add a second (physical) state to the HT model, then investigate how interstate banking alters the impact of these shocks. Both are still contractionary, but the magnitudes change: bank capital shocks in state A have a smaller impact with interstate banking, but the impact of collateral shocks gets bigger. The derivatives are complicated functions of the frictions in the model, but the logic is straightforward: a holding company that operating in two states can import capital to state A if lending opportunities there are still good, but a collateral shock in state A will lead the holding company to export capital and lending away from that state. In essence, interstate banking immunizes states against bank capital shocks, but exposes them to collateral shocks.

Rather than trying to identify these effects separately (the econometric equivalent of laser surgery), we first investigate whether the net impact of integration has made state economies more or less stable. ${ }^{1}$ Table 1 suggests the answer. As states' banking systems integrated, the state-specific variation in employment, variation that can be not be attributed either to aggregate business cycles or to differences in average growth across states, fell. Volatility in each state declines by more than one-half, from $2.4 \%$ in the late 1970s to $1.1 \%$ in the middle 1990 s. $^{2}$ Personal income growth displayed a similar trend; we include these figures in Panel B to show that there was no trend decline toward lower

\footnotetext{
${ }^{1}$ Banks and firms share risk to some extent, so they end up inheriting each other's problems. The precise division of those risks (and the bad outcome) would depend in a complicate way on ex ante contracts and ex post bargaining power. Nor do we consider the welfare benefits of integration, but presumably welfare rises as volatility falls.

2 These figures are the root mean squared error from a regression of state employment growth on a time effect (to remove aggregate cycles) and a state effect (to remove state differences in mean growth). See Table 1 for details.
} 
state-specific volatility during the 1960s and 1970s, prior to deregulation-induced bank integration. $^{3}$

Our more detailed results suggest that the (negative) correlation between state volatility and bank integration is more than coincidence. Using a panel of state-year data on employment growth over 1976-1994, we link fluctuations in employment growth around the state-year average to banking integration and find that it fell significantly as banks became increasingly integrated (via holding companies) with out-of-state banks. Our panel lets us control for trends in volatility across all states (due to macro changes), so we can isolate how state-specific changes in integration are linked with state-specific changes in volatility. Integration may be partly endogenous, so as a precaution, we use instruments for integration. Controlling for the composition of employment in each state, and the degree of concentration, strengthens the result. The stabilizing benefits of bank integration are most pronounced in the state with the least diversified economies - farm or energy states, for example.

The net stabilizing we find suggests that the insurance or diversification against bank capital shocks associated with integration more than offset any amplified effect on collateral. In fact, we show that the link between bank capital growth and employment growth within states falls substantially as banks in that state tighten ties to banks in other states. That is certainly consistent with our conclusion that integration over the last quarter century has helped stabilize state economic activity by helping banks diversify against shocks to their own capital.

\footnotetext{
${ }^{3}$ Personal income growth is a somewhat less reliable measure of economic activity that occurs within a state than employment growth because it attributes income generated from returns on capital earned anywhere to individuals living within the state. For this reason, we will focus the remainder of our empirical analysis on state employment growth.
} 
Although our focus here is on volatility in state economies, integration has important implications for bank stability and risk as well; operating across many states should have obvious diversification benefits, although how that plays out in terms of banks' risk taking is less obvious (Demsetz and Strahan, 1997).

\section{Interstate Banking}

Capital and banking market integration have been considered in a variety of contexts. The international literature on capital market integration (across nations) focuses mostly on the risk-sharing benefits of integration; cross-country diversification of asset portfolios tends to smooth aggregate consumption within nations. We doubt that banking integration in the U.S. has important risk-sharing effects for savers since they could always diversify via the stock market. In fact, Asdrubali et al. (1996) find that U.S. capital markets play a more vital role in income and consumption smoothing across states than do credit markets. The international literature does find, however, that increased capital market integration may actually amplify the own-country effect of productivity shocks as capital is able to flee a country afflicted with a productivity slump. Our model of interstate banking has some of that flavor.

Williamson (1989) compares the unit banking system in the U.S. to the more integrated system in Canada. Using an equilibrium costly monitoring model, he argues that the cross-province banking there should have stabilized the Canadian banking system relative to the U.S. unit banking system. His model also implies, somewhat counterintuitively, that integration amplifies the impact of aggregate real shocks. Integrated 
banking systems are less volatile, in other words, but the economy as a whole becomes more volatile. 4

Our paper, by contrast, investigates how banking integration affects state volatility (rather than bank or aggregate volatility). Our model introduces a second physical state to the (unit) banking model in Holmstrom and Tirole (1997) to illustrate how interstate banking can alter the impact of various shocks and thus affect the amplitude of the business cycle. As it turns out, interstate banking is not necessarily stabilizing because some types of shocks get dampened, but other types get amplified.

\section{II.1 The Holmstrom and Tirole Model}

The HT model comprises three players: firms, financial intermediaries, and investors. All are risk neutral. Firms have access to identical project technologies, but they differ in their initial capital endowments: $A_{0}$. Financial intermediaries ("banks") and investors can both lend to firms, but only the banks have monitoring know-how; the uninformed investors must rely on monitoring by the banks. Investors have access to an alternative investment opportunity.

Technology. Firms choose between a good project and either of two bad projects. The "good" project succeeds with probability $p_{H}$; both "bad" projects succeed with probability $p_{L}$. A key parameter in the model is the good and bad projects' relative likelihood of success: $\Delta p=p_{H}-p_{L}>0$. All of the projects return $R$ per-unit invested if they are successful and 0 if not. $R$ is public. The two bad projects also

\footnotetext{
4 The counterintuitive result that integration amplifies the effect of real shocks seems to stem from the type of shock considered (a mean preserving increase in the projected technology risk) and on a hard-toexplain effect of bank diversification on the elasticity of credit demanded by firms. His evidence from the pre-War period is mixed.
} 
produce differing amounts of private benefits (to the firm): type $b$ bad projects produce a small private benefit $(b)$; type $B$ bad projects produce a larger private benefit $(B>b)$.

Moral Hazard and Monitoring. Moral hazard arises because of the private benefits from bad investments; firms may choose bad projects over good projects (with higher expected returns) because the former produce private (i.e., unshared) benefits. Monitoring by a bank can prevent type $B$ investment, but not type $b$ investment. The idea here is that monitoring is an effective deterrent against obvious fraud and abuse (e.g., simply absconding with the borrowed funds), but smaller abuses, (shirking, etc.) must be remedied through incentive schemes. Monitoring costs are proportional to the amount invested; if investment is $I$, monitoring costs $=c I$. Monitoring is itself a private activity, in that savers cannot determine if bankers have actually monitored a given firm. Private monitoring creates a second moral hazard; unless it is worthwhile, bankers will only pretend to monitor. Banks must invest enough of their own capital in the project to ensure that they will monitor adequately. ${ }^{5}$

Contracts. Firms will always choose a mix of liabilities, borrowing from both the bank and investors. If the project succeeds, the firm, bank monitor, and uninformed investors receive $R f, R m$ and $R u$. These shares are determined endogenously by the opportunity costs of the three parties. We prefer the intermediation interpretation of financing structure offered by HT: investors deposit their money with the bank, and banks fund the firms they monitor with those deposits and the bank's own capital. The

\footnotetext{
${ }^{5}$ Project risk is not completely diversifiable so banks need a stake in the project (or else they would shirk on monitoring).
} 
bank's ability to attract deposits depends on its own capital (which is needed to assure uninformed investors that it will monitor firms adequately). ${ }^{6}$

Equilibrium and Comparative Statics. Given the rates of return required by investors $(\gamma)$ and banks ( $\beta$ ), a firm with initial assets $A_{0}$ chooses investment (I), its own capital contribution (A), and its mix of liabilities to maximize its expected profits:

$$
\begin{aligned}
\max U\left(A_{0}\right) & =p_{H} R I-p_{H} R m-p_{H} R u+\gamma\left(A_{0}-A\right) \quad \text { subject to: } \\
R I & \geq R f+R m+R u \\
R f & \geq b I / \Delta p \\
R m & \geq c I / \Delta p
\end{aligned}
$$

The main budget constraint (1) limits the sum of returns to the three parties to the total return on the investment. ${ }^{7}$ Eq. (2) is an incentive constraint on the firm; the gain in expected payments to the firm from choosing the good project cannot be less than the private benefit from choosing the first bad project. Eq. (3) is an incentive constraint on the intermediary; the expected gain in return to the bank from forcing the firm to choose the good project must exceed the cost of monitoring, else the bank will not monitor. At the optimum, all constraints will bind so Eq. (1)-(3) define the maximum income the project owner can pledge to uninformed investors: $p_{H}(R-(b+c) / \Delta p)$, i.e. the maximum payment per unit of investment that can be promised to uninformed investors without violating incentives.

\footnotetext{
${ }^{6}$ Under the certification interpretation, uninformed investors invest directly in the firm, but only after the monitor has taken a large enough financial interest in the firm that the investor can be assured that the firm will behave diligently.
} 
All firms choose the same optimal policy per unit of own capital, so an economywide equilibrium is easily found by aggegating across firms. Let $K f$ be the aggregate amount of firm capital, $K m$ the aggregate amount of informed capital, and $K u$ the aggregate supply of uninformed capital. The first two are fixed, while the third is determined so that the demand for uninformed capital (the sum of the pledgeable expected returns of individual firms, discounted by $\gamma$ ) equals the supply of uninformed capital. Let $\gamma(K u)$ be the inverse supply function, and let $K=K f+K m+K u$ is the total amount of capital invested. The equilibrium rate of return on uninformed capital is determined by

$$
\gamma(K u)=p_{H} K(R-(b+c) / \Delta p) / K u
$$

The equilibrium rates of return in informed capital markets is determined by

$$
\beta=p_{H} c \cdot K /(K m \cdot \Delta p),
$$

Holmstrom and Tirole show how shocks to each player's capital affect the equilibrium returns to investors $(\gamma)$ and banks $(\beta)$ and the rate of investment by firms. A decrease in informed capital (a capital "crunch") decreases $\gamma$ and increases $\beta$. A fall in firms' capital (a collateral "squeeze") decreases $\gamma$ and decreases $\beta$.

The model can also be used to examine how the two types of shock affect the availability of external finance and firms' investment spending. First, there is a direct contractionary effect due to the fact that the capital crunch and the collateral squeeze lead to a reduction in the amount of capital that can be invested in the firm by the bank and by the entrepreneur, respectively. Second, there is an indirect contractionary effect due to the

\footnotetext{
7 The other budget constraints (i,ii,iii and iv HT p. 680) are omitted here for brevity.
} 
fact that the collateral squeeze and the capital crunch reduce the pledgeable income that can be promised to uninformed debtholders without destroying incentives. The decrease in the pledgeable income affects negatively firms' ability to attract uninformed capital (see equation 1a).

\section{II.2 Interstate Banking in the HT Model}

We extend the HT model to interstate banking by simply adding another physical state. The only subtlety is in the treatment of capital mobility across states under the two banking regimes (unit and interstate) that we want to compare. For simplicity, we make the extreme assumption that informed capital is completely immobile across states under unit banking. In other words, unit banking is equivalent to the single state world HT considered. At the opposite extreme, we assume that informed capital is completely mobile across states under interstate banking. These extreme assumptions are not necessary for our results below, however; we obtain qualitatively similar results so long as informed capital is relatively less mobile under unit banking. Note that we also assume that the return on uninformed capital is exogenous and equal across states for both unit banking and interstate banking. This is consistent with the fact that uninformed investors have access to a nation-wide securities market regardless of the banking regime. On this securities market, there is a quasi-unlimited supply of investment opportunities, with a rate of return independent of state-specific shocks.

The appendix contains details on the extended model, the equilibrium, and the comparative statics. In short, the own-state effect of a bank capital shock is diminished under interstate banking because bank capital can flow from other states that did not experience a shock. The own-state impact of a firm collateral shock is amplified under interstate banking because banks in the affected state are free to shift their lending across 
the border to firms with better collateral. Thus, the net effect of integration on volatility is ambiguous. The following propositions compare the impact of the two shocks under unit banking and interstate banking.

Proposition 1: with interstate banking, the negative impact of a bank capital crunch in state 1 on the amount of uninformed and informed capital invested in that state is smaller than with unit banking. The intuition for this result is that with interstate banking, the increase in $\beta$ caused by the bank capital crunch will attract bank capital from state 2 . This will mitigate the impact of the bank capital crunch on the availability of external finance in two ways. First, the bank capital inflow leads to a lower decrease in the amount lent by banks to firms in state 1 . Second, because the amount lent by banks to firms in state 1 decreases less, we also have a smaller reduction in the pledgeable income that can be promised to uninformed investors by firms in state 1 without breaking incentives. As a result, we have a smaller reduction in the amount of uninformed capital that firms in state 1 can attract. With unit banking, these mitigating effects do not take place, since bank capital cannot move across states.

Proposition 2: with interstate banking, the negative impact of a collateral squeeze in state 1 on the amount of uninformed and informed capital invested in that state is larger than with unit banking. The intuition for this result is that with interstate banking, the decrease in $\beta$ following the collateral squeeze will induce bank capital to move to state 2. Here again, two effects must be distinguished. First, the bank capital flight leads to a decrease in the amount lent by banks to firms in state 1 . Second, because of this reduction of the amount lent by banks to state 1 firms, we also have a decrease in the pledgeable income that can be promised to uninformed investors. As a result, there is a 
reduction of the amount of uninformed capital that state 1 firms can attract. With unit banking, these amplifying effects do not take place, since bank capital cannot move across states.

In sum, cross-state banking amplifies the effects of local shocks to entrepreneurial wealth because bank capital chases the highest return. Capital flows in when collateral is high and out when it is low. Integration dampens the impact of bank capital supply. This source of instability becomes less important because entrepreneurs are less dependent on local sources of funding in an integrated market since bank capital can be imported from other states.

\section{Empirical Strategy and Data}

Identifying exogenous components of the two kinds of financial shocks just discussed seems like a difficult task. Even with the requisite data, the high correlation between bank capital and borrower collateral would require strong and perhaps implausible identifying assumptions. Instead, we first ask a more tractable (but still useful) question: how has banking integration across states affected overall volatility within states? Do state-specific business fluctuations get bigger or smaller as banks in the state become increasingly integrated with banks in other states? We know from the model that if bank capital shocks are more a source of volatility than collateral shocks, the net effect of integration should be stabilizing. Integration, in other words, should reduce volatility. We then offer tentative evidence suggesting that the effects of the two kinds of financial shocks change in ways consistent with our model, with the caveat that we have no good instruments to identify the exogenous components of these shocks.

\section{Endogenous Integration?}


Reverse causality of two sorts concerns us. First, increased cross-state banking may indicate merely that states' economies are becoming more integrated; banks may simply follow their customers across state lines. If so, and if "real" integration (as opposed to bank integration) affects business volatility, our results may confuse the effects of real vs. bank integration. Reverse causality could arise also via banking "hangovers" (from too much farming, or too much oil), as the associated distress and volatility may attract bargain-hunting banks from other states. (In fact, we find evidence of this idea below.) To guard against these or other potential endogeneity problems, we instrument for integration using an indicator equal to one after a state entered an interstate banking agreement, and the number of years elapsed since the agreement.

\section{A Brief History of Interstate Banking}

Restrictions on interstate banking in the U.S. date back to the infamous Douglas Amendment to the 1956 Bank Holding Company (BHC) Act. With that amendment, banks or holding companies headquartered in one state were prohibited from acquiring banks in another state unless such acquisitions were permitted by the second state's government. No states allowed such transactions in 1956, so the amendment effectively barred interstate banking. Change began in 1978, when Maine passed a law allowing entry by out-of-state BHCs if, in return, banks from Maine were allowed to enter those states (entry meaning the ability to buy incumbent banks). No states reciprocated, however, so the integration process remained effectively stalled until 1982, when Alaska, Massachusetts, and New York passed laws similar to Maine's. ${ }^{8}$ State deregulation was

\footnotetext{
${ }^{8}$ As part of the Garn-St Germain Act, federal legislators amended in 1982 the Bank Holding Company Act to allow failed banks and thrifts to be acquired by any bank holding company, regardless of state laws (see, e.g., Kane (1996) and Kroszner and Strahan, 1999).
} 
nearly complete by 1992 , by which time all states but Hawaii had passed similar laws. ${ }^{9}$ The process was completed in 1994 with the passage of the Interstate Banking and Branching Efficiency Act of 1994 (IBBEA) that mandated complete interstate banking as of 1997 and gave states the option to permit interstate branching. ${ }^{10}$

This roughly 15-year history provides an excellent opportunity to test how the resulting integration has affected volatility. Luckily for us, the states did not deregulate all at once, and the subsequent integration across states proceeded at different rates (Chart 1). The staggered deregulatory events provide us with both cross-sectional and time series variation with which to identify the effects of integration; also, the deregulatory events themselves provide a good instrument for integration. ${ }^{11}$

\section{Measuring Integration and Volatility}

Our measure of bank integration equals the share of total bank assets in a state that are owned by bank holding companies that also hold banking assets in other states (or other countries). To illustrate, if a state had one stand-alone bank and one affiliated bank of equal size, integration in that state would equal $1 / 2$.

We associate volatility with the year-to-year deviations (from average) in measures of business activity. Starting with the annual growth rate of series $x$ for state $i$ in year $t$, we first subtract off the mean growth rate in $x$ for state $i$ over time.

"Demeaning" by the state average removes long-run growth differences across states.

We then subtract off the mean growth rate of series $x$ across states in year $t$. Demeaning

\footnotetext{
${ }^{9}$ State-level deregulation of restrictions on branching also occurred widely during the second half of the 1970 s and during all of the 1980s.

${ }^{10}$ IBBEA permitted states to opt out of interstate branching, but only Texas and Montana chose to do so. Other states, however, protected their banks by forcing entrants to buy their way into the market.
} 
by the national average each year helps control for aggregate business fluctuations. We are left with the state-specific shock to our measure of business activity. Our volatility measures will be the square of the resulting deviations, the log of the squared deviations, or the absolute value of these deviations.

Our sample starts in 1976, a few years before interstate deregulation began. We end the sample in 1994, the year that the Riegle-Neal Interstate Banking and Branching Efficiency Act became law. Riegle-Neal allowed bank holding companies to acquire banks in any state after September 29, 1995 and permitted mergers between banks in different states as of June 1, 1997, which effectively allowed nationwide branch networks. The law also gave states the right to adopt an earlier starting date for interstate bank mergers, however, and about half of the states did so (Spong, 2000). In response, banks such as NationsBank consolidated operations from several other states into its primary North Carolina bank (NationBank NC N.A.), leading to an increase of this bank's (and hence North Carolina's) assets from $\$ 31$ billion in 1994 to $\$ 79$ billion in 1995. Because of this cross state consolidation, we lose the ability to measure bank assets meaningfully at the state level after 1994.

Our two measures of business activity are the annual growth rates of total state employment and small-firm employment, where we define a small firm as one with fewer than 20 employees. ${ }^{12}$ Numbers on total employment are available from 1976-94 from the Census Bureau. Small-firm employment comes from the Bureau's County Business

\footnotetext{
${ }^{11}$ While we focus here on interstate banking, Jayaratne and Strahan (1996) report that state-level growth accelerated following branching deregulation; Jayaratne and Strahan (1998) show that branching deregulation led to improved efficiency in banking.

12 The employment data from the County Business Patterns are stratified by establishment size rather than firm size. Thus, there may be some misclassifications in cases of large firms operating many small-scale plants.
} 
Patterns series, starting in 1977 (1978 after converting to growth rates). ${ }^{13}$ In principle, the more bank-dependent firms in the latter category may be more affected by banking integration. To isolate the volatility that is specific to these small firms, we remove the state-specific shock to employment that is common to both small and large firms before constructing our measure of volatility. We do this by regressing small-firm employment growth on the state effect (removes the long-run state mean growth rate), the time effect (removes the current aggregate business cycle) and the growth rate in employment at large firms (those with more than 250 employees). We use the residuals from this regression to construct our measures of small-firm volatility. ${ }^{14}$

Table 2 reports summary statistics for the integration and volatility measures. The average share of integrated bank assets over the full sample of state-years was 0.34 , rising from under 0.1 in the 1970 s to about 0.6 by the mid-1990s. Overall employment grew 2.3 percent per year on average over the sample of state-years. The squared deviation of employment growth from its mean averaged 0.03 percent, and, perhaps more interpretable, the absolute deviation of employment growth averaged 1.3 percent. Smallfirm employment growth was slightly more volatile than overall employment growth, averaging 0.04 percent for squared deviations and 1.4 percent for absolute deviations. We also control for the share of employment in a given state/year in each of eight broad industrial categories (one-digit SIC), along with the sum of squared shares in these

\footnotetext{
${ }^{13}$ The small firm and total employment data are not directly comparable as the former excludes selfemployed individuals, employees of private households, railroad employees, agricultural production employees, and most government employees. We drop Delaware and South Dakota as these two states' banking sectors are dominated by credit card banks due to their liberal usury laws. See Jayaratne and Strahan, 1999 for details.

${ }^{14}$ The justification for this procedure is a pragmatic one. We are comfortable that firms with fewer than 20 employees ought to be viewed as "small", and that firms with more than 250 are "large." In between lies a difficult-to-categorize group of firms. We therefore leave these firms out in trying to isolate the shock to employment growth at small firms.
} 
groups as a measure of the diversification across industries in a given state/year. (We call the diversification index the "labor share HHI".) The summary statistics for these variables are also reported in Table 2.

\section{Results}

\section{IV.1 State Business Volatility Declines with Bank Integration}

In view of the ambiguous theoretical relationship between integration and volatility, we choose to report a variety of relationships. We have two growth measures (total employment and small-firm employment) and three ways to define volatility. Also, for each dependent variable, we report both a fixed effects regression (OLS) and an instrumental variable (IV) estimate. IV seems advisable because the pace of integration may itself depend on volatility as noted earlier. We use two instruments in the first stage: an indicator variable equal to zero before a state entered an interstate banking agreement with other states and one after; and a continuous variable equal to zero before interstate banking, and equal to the log of the number of years that have elapsed since a state entered an interstate banking arrangement with other states. ${ }^{15}$

As noted, employment volatility will obviously depend on labor force composition, so we also control for the share of employment in each one-digit SIC sector (manufacturing, services, etc.) and employment concentration (the sum of the squared shares). In all specifications we control for the year and state, so the resulting fixed effect estimates reveal how increased integration within a state in a given year is related to volatility within the same state and year. ${ }^{16}$

\footnotetext{
${ }^{15}$ In the first stage models, both instruments have very strong explanatory power. These regressions are available on request.

${ }^{16}$ But other important changes occurred during the 1980s, such as rapid adoption of sophisticated financial models and increased use of securitization, not just for residential mortgages but also for consumer loans,
} 
Tables 3 and 4 report the estimated coefficients for the twelve specifications. For overall employment growth, all of the estimates are negative, and five of the six are statistically significant at the five percent level (Table 3). Integration has had, on net, a stabilizing influence on state business volatility. In addition, the IV coefficient estimates are much larger than the corresponding OLS estimates in all three cases, implying that the stabilizing influence of integration is larger (if less precisely estimated) when we use deregulation variables to parcel out the endogenous variation in integration. ${ }^{17}$ In fact, the portion of integration that is orthogonal to deregulation is strongly positively related to employment volatility (not reported), perhaps because out-of-state banking companies opportunistically enter new states when banks in those states are facing difficulties associated with an economic downturn. (Remember: banks enter new states by buying their way in.) $)^{18}$

We do not find evidence in these regressions that diversification across industries, measured by the labor share HHI index, reduces volatility, as one might expect. There is very little time-series variation in this index, however, making it difficult to measure its coefficient in the fixed effects models. If we drop the state fixed effects and estimate the

commercial real estate loans and even commercial and industrial loans (Mishkin and Strahan, 1999). These new technologies seem to have increased the efficient scale in banking and may be responsible, in part, for greater integration. For an exhaustive review of the causes and consequences of financial consolidation in the U.S., see Berger, Demsetz and Strahan (1999).

17 One might object that interstate banking deregulation itself may be determined, in part, by the volatility of a state's business cycle. For example, perhaps political pressure for opening a state's banking system to out-of-state competition intensifies during economic downturns (when volatility is high). To rule out the possibility that endogenous deregulation drives our IV results, we have also estimated the model after dropping the 3 years just prior to deregulation as well as the year of deregulation itself. In these specifications, the coefficient increases in magnitude (i.e. becomes more negative), and its statistical significance increases across all three measures of volatility.

${ }^{18}$ We have also estimated this model with a full set of interactions between the year effects and the statelevel industry employment share variables in order to allow the impact of the aggregate shock to depend on a state's industry mix. These results give very similar results for the effect of integration on volatility (i.e. negative and statistically significant). 
model with random effects instead, the labor share HHI does enter the regression with a positive and statistically significant coefficient (not reported).

We also find declines in employment growth volatility at small firms, where we expect the influence of banking, and hence banking integration, to be most important (Table 4). Here, we find a statistically significant effect of banking integration on volatility in five of our six specifications. Moreover, the declines in volatility are larger for the small firms than for overall employment in all of the IV specifications.

The IV estimates for both overall and small-firm employment imply a substantial stabilizing benefit from integrating bank assets across states. The share of integrated bank assets rose from around 10 percent in 1976 to around 60 percent in 1994; the reduced form model (not reported) suggests that about one-half of this increase can be attributed to interstate deregulation, or an increase in integration of 25 percent. Based on the coefficient from the IV model, this 25 percent increase in integrated bank assets reduced the absolute deviation of overall state employment growth by 0.9 percent (Table 3, column 6). This decline is very large relative to the mean (1.3 percent) and standard deviation (1.2 percent) over the whole sample. For small-firm employment, the IV estimate suggests that the 25 percent increase in integrated bank assets led to a drop in volatility of 1 percent (Table 4, column 6).

Table 5 reports two slightly more complex models in which we test whether banking integration reduces volatility more in states relatively reliant on one or a few sectors. A well-diversified state will tend to have well-diversified (unit) banks too, thus reducing the potential stabilizing effect of integration. In contrast, in a state that relies heavily on one or two sectors, banks constrained to operating only there will also rely on 
those one or two sectors. Integrating these banks ought to have greater benefits, and the results suggest that it has.

We provide two tests of this idea. First, we interact the labor-share HHI with our integration variable (Panel A); second, we estimate the basic model separately for large states (states with above-median income in 1975) and small states (Panel B). Both approaches support the idea that banking integration stabilizes small and specialized economies more than large and well-diversified economies. First, we estimate a negative and significant coefficient on the interaction of HHI with integration, meaning that the effect of banking integration is more negative in states with more specialized economies (Panel A). ${ }^{19}$ Second, we estimate a negative effect of banking integration for small states using all three measures of volatility, and the coefficient is statistically significant in two of the three specifications. In contrast, the measured effect of banking integration on volatility is never significant.

\section{IV.2 How Integration Changes the Correlation between Bank Capital, Collateral and}

\section{Business Activity}

We have not directly tested our model of integration due to the difficult task of identifying exogenous and independent shocks to bank capital and to entrepreneurs' collateral. ${ }^{20}$ In this section, however, we offer tests of how the correlation between proxies for these shocks changes with integration, without attempting to find the exogenous portion of each shock. We estimate how local employment growth and

\footnotetext{
${ }^{19}$ Note, however, that the interaction term between the labor share HHI and banking integration loses statistical significance when we drop Wyoming, the state with the most specialized economy in the U.S.

${ }^{20}$ Peek and Rosengren (2000) used the downturn in Japan to identify an exogenous decline in bank capital. They show that when Japanese banks faced financial difficulties in the 1990s, they reduced their lending in California, leading to a decline in credit availability there. This finding is consistent with our model,
} 
lending growth correlate with local bank capital growth (a proxy for bank capital shocks) and with growth in local housing prices (a proxy for collateral shocks), and how these correlations change in response to banking integration. To be precise, we regress state employment growth and aggregate growth of total bank loans and business loans on 1) the growth in aggregate capital held at all banks in the state, and 2) the growth in Freddie Mac's index of housing prices in the state 3) our measure of banking integration, and 4) interactions between integration and the two local "shocks". We also include state and year fixed effects. According to our interstate version of the HT model, the correlation between bank capital growth and economic activity (employment growth and loan growth) ought to decline with integration, implying a negative coefficient on the interaction term. The correlation between housing prices and activity ought to increase with integration, implying a positive interaction term. ${ }^{21}$

The results support these implications (Table 6). As states integrate, local bank capital becomes much less correlated with all four measures of local economic activity. ${ }^{22}$ For example, prior to banking integration, a one standard deviation decline in bank capital growth (a decline of 8.5 percent) was associated with a reduction in employment growth of 1.2 percent (Panel A, column 1). Based on the mean level of banking integration in 1994 (0.6), the end of our sample, the model suggests that a one standard

although it emphasizes the downside of integration. While integration insulates an economy from shocks to its own banks, it simultaneously exposes an economy to banking shocks from the outside.

${ }^{21}$ Other researchers have investigated how holding company affiliation, a concept related to our measure of banking integration, affects bank lending properties; Houston and James (1997) find that lending by affiliated banks is less sensitive to the bank's own cash flow, suggesting the holding company operates as an internal capital market. Ashcraft (2001) finds that lending by affiliated banks is less sensitive to changes in monetary policy (i.e., changes in the federal funds rate) than is lending by unaffiliated banks.

${ }^{22}$ We have also estimated these regressions using IV, where an instrument for integration is constructed from an indicator variable equal to one after state-level interstate banking reform and a continuous variable equal to the $\log$ of the number of years elapsed since reform. These results are similar to those reported in Table 6. 
deviation decline in bank capital growth would be associated with a decline in employment of just 0.3 percent. We find similar effects of banking integration on employment growth at small firms; bank capital matters a lot prior to integration but much less after, although both the direct effect of capital, as well as the interaction term, are larger in magnitude for small-firm employment growth.

Table 6 also shows that the link between bank capital and loan growth declined sharply after banking integration. Prior to integration, a standard deviation increase in bank capital was associated with an increase in business lending of 5.7 percent and an increase in total lending of 5.5 percent. With integration that prevailed in 1994, the same increase in local bank capital was associated with just a 3.1 percent increase in business lending and a 4.2 percent increase in total loans.

The correlation between housing prices (collateral) and local economic conditions, again consistent with our model, strengthens following integration. For example, a standard deviation decrease in housing prices $(0.078)$ would be associated with a decline in employment of 0.4 percent ( 0.4 percent for small firms) before integration, but a decline of 0.7 percent ( 0.9 percent for small firms) after integration. The same decline in housing prices would be associated with a drop in business lending of 1.1 percent (1.0 percent for total lending) before integration, but a decline of 4.1 percent (2.8 percent for total lending) after integration. These changes are all statistically significant at the 5 percent level or better.

\section{IV.3. Bank Integration vs. Real Integration?}

The negative correlation between bank integration and state business volatility is probably not an artifact of increased real integration-increased trade that is — among the 
states. It is not obvious that trade among states even stabilizes production within states, as trade may reflect specialized production and specialization is the opposite of diversification. Even if we suppose that trade has stabilizing effect, the change in bank integration and trade integration are not correlated during our sample period (Chart 2). The only qualifier necessary here relates to our proxy for "real" or trade integration: outof-state shipments for each state expressed as a percentage of total shipments. These data are collected as part of the Commodity Flow Surveys conducted by the Department of Transportation and the Department of Commerce. While these are the best, most frequently available data, they are not perfect. The 1977 survey covered only manufacturers, while the 1993 included wholesale trade firms as well. Wholesalers tend to ship shorter distances (Hillberry and Hummel, 2002), so their inclusion in the 1993 tends to lower look lower relative to 1977. As long as that survey bias is not correlated with the change in bank integration over the 1977 to 1993, our point in Chart 2 goes through: the negative correlation we have found between bank integration and business volatility does not reflect trade integration in disguise.

\section{Conclusions}

The U.S. used to have 50 little banking systems, one in every state. Now, some 15 years after states opened their borders to other states' banks, we have a much more integrated banking system, with holding companies operating banks across many states. As a theoretical matter, the impact of cross-state banking on business volatility is ambiguous because integration immunizes borrowers from shocks to their own banks but exposes them to shocks to their own wealth. We find that the fragmented business of U.S banking before the mid-1980s was, in all likelihood, a source of state business volatility. 
On net, integration was stabilizing; employment growth fluctuations in a state diminished as its banks commingled with other states' banks. State business cycles have become smaller, in other words, but more alike. As the French say: the more things change, the more they stay the same.

Our findings here also bear on developments in Europe, where banks are just starting to integrate across nations. ${ }^{23}$ Applied there, our findings imply that further bank integration abroad should lead to smaller, but more correlated, national business cycles. More generally, our results may inform thinking about worldwide financial integration, since "globalization" is just a scaled-up version of the national integration studied here.

Better bank integration may also be a factor behind the decline in aggregate U.S. economic volatility over the past twenty years noted by McConnell and Perez-Quiros (2000) and Blanchard and Simon (2001). ${ }^{24}$ The possible mechanisms that have been proposed to explain this stabilization trend are 1) better inventory management (Kahn, McConnell and Perez-Quiros, 2002), 2) reduced volatility of sales with non-convexities in the production process (Ramey and Vine, 2001), 3) better monetary policy (Blanchard and Simon, 2001), and 5), better luck (Stock and Watson, 2001). Our results suggest adding better finance to the list. In fact, access to finance is a crucial piece of the inventory-management hypothesis. According to this view, firms began smoothing production better in the post-1984 period by building up inventories during period of low

\footnotetext{
${ }^{23}$ Garcia Blandon (2001) finds that foreign bank entry in Europe is impeded by various non-regulatory barriers, such as cultural distance between consumers, while export levels and the presence of multinationals are positively correlated with foreign bank penetration.

${ }^{24}$ McConnell and Quiros (2002) mark the break in volatility at 1984. Blanchard and Simon argue that volatility has trended down since the 1950s, with the 1970s being an aberration to that trend.
} 
sales growth, and vice versa during period of high sales growth. ${ }^{25}$ These counter-cyclical movements in inventories are only possible if firms can finance inventory investment when cash flow (sales) is low. In other words, counter-cyclical inventory investment is only possible if external finance is available and affordable during downturns. Exploring the link between improved bank finance and aggregate decline in aggregate volatility would make an interesting paper.

${ }^{25}$ In fact, the correlation between sales growth and inventory investment went from positive to negative after 1984 (Kahn, et al, 2002). 


\section{References}

Ashcraft, Adam, "New Evidence on the Lending Channel," Federal Reserve Bank Staff Study 136, September 2001.

Bernanke, B., and M. Gertler, "Banking and Macroeconomic Equilibrium," in New Approaches to Monetary Economics, W. Barnett and K. Singleton, eds. (New York and Melbourne: Cambridge University Press, 1987).

Berger, Allen N., Rebecca S. Demsetz, and Philip E. Strahan (1999), "The Consolidation of the Financial Services Industry: Causes, Consequences, and Implications for the Future," Journal of Banking and Finance, Vol. 23, No. 3-4, 135-194.

Blanchard, Olivier and John Simon, 2001, "The Long and Large Decline in U.S. Output Volatility," Brooking Papers on Economic Activity no. 1, 135-74

Clark, T., and E. Wincoop, "Borders and Business Cycles," Forthcoming in Journal of International Economics, 2000.

Demsetz, Rebecca S. and Philip E. Strahan (1997), "Size, Diversification and Risk at US Bank Holding Companies," Journal of Money, Credit and Banking, Vol. 29, 300-13.

Feldstein, Martin, 1997, EMU and International Conflict, Foreign Affairs, 76, 60-73.

Garcia Blandon, Josep, Cross-border Banking in Europe: An Empirical Investigation, Working paper No 509, October 2000, Universitat Pompeu Fabra. 2000.

Hillberry, Russell, and D. Hummels, 2002, "Intra-national Home Bias: Some Explanations,” NBER Working Paper 9022

Holmstrom, B., and J. Tirole, "Financial Intermediation, Loanable Funds, and the Real Sector,” Quarterly Journal of Economics, CXII (1997), 663-691.

Houston, Joel, Christopher James, and David Marcus, 1997, "Capital Market Frictions and the Role of Internal Capital Markets in Banking," Journal of Financial Economics 46, 135-164.

Jayaratne, Jith and Donald P. Morgan, 1999, "Capital Market Frictions and Deposit Constraints on Banks," Journal of Money, Credit and Banking.

Jayaratne, Jith and Philip E. Strahan (1996), "The Finance-Growth Nexus: Evidence from Bank Branch Deregulation," Quarterly Journal of Economics, Vol. 111, 639-670.

(1998), "Entry Restrictions, Industry Evolution, and Dynamic Efficiency: Evidence from Commercial Banking, The Journal of Law and Economics, Vol. XL1 (1), 239-273. 
Kahn, James A., Margaret McConnell and Gabriel Perez-Quiros, 2002, "On the Causes of the Increased Stability of the U.S. Economy," Federal Reserve Bank of New York, Economic Policy Review, May 2002.

Kane, Edward (1996), "De Jure Interstate Banking: Why Only Now?," Journal of Money, Creidt, and Banking, Vol. 28, May, 141-161.

Kroszner, Randall S. and Philip E. Strahan (1999), "What Drives Deregulation: Economics and Politics of the Relaxation of Bank Branching Restrictions," Quarterly Journal of Economics, Vol. 114, No. 4, 1437-67.

McConnell, Margaret and Gabriel Perez-Quiros, 2000, "Output Fluctuations in the United States: What has Changed since the Early 1980s?” American Economic Review 90(5), 1464-76.

McPherson, S., and C. Waller, "Do Local Banks Matter for the Local Economy? In Search of a Regional Credit Channel," Forthcoming in International Macroeconomics, G. Mess and E. Wincoop, eds., (Cambridge University Press, 1999).

Peek, Joseph and Eric Rosengren (2000), "Collateral Damage: Effects of the Japanese Bank Crisis on the United States," American Economic Review (March), 30-45.

Ramey, Valerie A., and Daniel J. Vine, 2001, "Tracking Sources of the Decline in GDP Volatility: An Analysis of the Automobile Industry," mimeo, December 28, 2001.

Spong, Kenneth (2000). Banking Regulation: Its Purposes, Implementation, and Effects. Federal Reserve Bank of Kansas City, Kansas City: MO.

Stock, James and Mark W. Watson, 2002, "Has the Business Cycle Changed and Why?" mimeo, August 2002.

Stockman, A., and L. Tesar, "Tastes and Technology in a Two-Country Model of the Business Cycle: Explaining International Comovements," American Economic Review, LXXXV (1995), 168-185.

U.S. Department of Transportation, Bureau of Transportation Statistics, 1993 Census of Transportation, Communications, and Utilities, Commodity Flow Survey, Washington, D.C.

U.S. Department of Commerce, Bureau of the Census, 1977 Census of Transportation: 1977 Commodity Transportation Survey Summary, Washington D.C.

Williamson, S., "Bank Failures, Financial Restrictions, and Aggregate Fluctuations: Canada and the United States, 1870-1913," Federal Reserve Bank of Minneapolis Quarterly Review, XIII (1989), 20-40.

Williamson, S., "Restrictions on Financial Intermediaries and Implications for Aggregate Fluctuations: Canada and the United States 1870-1913," in NBER Macroeconomics Annual: 1989, O. Blanchard and S. Fischer, eds. (Cambridge, Mass. And London: MIT Press, 1989). 


\section{Appendix: Comparative statics in the HT Model with unit and interstate banking}

\section{Equilibrium with unit banking}

With unit banking and assuming $\gamma$ exogenous, equilibrium on the uninformed capital market in state 1 obtains when

$$
p_{H}\left(K f_{1}+K m_{1}+K u_{1}^{u}\right)(R-(b+c) / \Delta p)=\gamma \cdot K u_{1}^{u} .
$$

Solving this equation, we obtain the equilibrium quantity of uninformed capital attracted by firms in state 1

$$
K u_{1}^{u}=\frac{p_{H}(-b-c+R \cdot \Delta p)\left(K f_{1}+K m_{1}\right)}{p_{H}(b+c-R \cdot \Delta p)+\Delta p \cdot \gamma} .
$$

Equilibrium in state 2 can be defined in a similar way.

\section{Equilibrium with interstate banking}

Interstate banking changes the equilibrium in the following way. Assuming capital can move freely across states, the shares $\pi_{1}$ and $\left(1-\pi_{1}\right)$ of aggregate informed capital $K m_{1}+K m_{2}$ invested in each state adjust endogenously to equalize the return on informed capital across states. When the share of informed capital invested in each state is endogenous, equilibrium in the uninformed capital market under interstate banking is defined by

$$
\begin{gathered}
p_{H}\left(K f_{1}+\pi_{1}\left(K m_{1}+K m_{2}\right)+K u_{1}^{i}\right)(R-(b+c) / \Delta p)=\gamma \cdot K u_{1}^{i} \\
p_{H}\left(K f_{2}+\left(1-\pi_{1}\right)\left(K m_{1}+K m_{2}\right)+K u_{2}^{i}\right)(R-(b+c) / \Delta p)=\gamma \cdot K u_{2}^{i} .
\end{gathered}
$$

The equilibrium rate of return on the bank capital market is: 


$$
\beta=p_{H} \cdot c \cdot K_{1} /\left(\Delta p \cdot \pi_{1}\left(K m_{1}+K m_{2}\right)\right)=p_{H} \cdot c \cdot K_{2} /\left(\Delta p\left(1-\pi_{1}\right)\left(K m_{1}+K m_{2}\right)\right) .
$$

With $K_{1}=K f_{1}+\pi_{1}\left(K m_{1}+K m_{2}\right)+K u_{1}^{i}$ and $K_{2}=K f_{2}+\left(1-\pi_{1}\right)\left(K m_{1}+K m_{2}\right)+K u_{2}^{i}$

Solving the system of equations defined by (3a)-(5a), we obtain the equilibrium quantities attracted by firms in each state and the share of informed capital invested in each state:

$$
\begin{aligned}
& K u_{1}^{i}=\frac{p_{H}(-b-c+R \cdot \Delta p)\left(K f_{1}+K f_{2}+K m_{1}+K m_{2}\right) K f_{1}}{\left(p_{H}(b+c-R \cdot \Delta p)+\Delta p \cdot \gamma\right)\left(K f_{1}+K f_{2}\right)} \\
& K u_{2}^{i}=\frac{p_{H}(-b-c+R \cdot \Delta p)\left(K f_{1}+K f_{2}+K m_{1}+K m_{2}\right) K f_{2}}{\left(p_{H}(b+c-R \cdot \Delta p)+\Delta p \cdot \gamma\right)\left(K f_{1}+K f_{2}\right)} \\
& \pi_{1}=\frac{K f_{1}}{K f_{1}+K f_{2}}
\end{aligned}
$$

\section{Comparative statics}

To get the intuition for proposition 1 and 2, we compare the equilibrium condition for unit banking (1a) and for interstate banking in state 1 (3a), after substitution of $\pi_{1}$ by its reduced-form solution in (8a). The equilibrium conditions for the two regimes are plotted in figure 1.

Let's first consider the bank capital crunch. With unit banking, the reduction in the pledgeable income is proportional to the reduction of $K m_{1}$. With interstate banking, by contrast, the reduction in the pledgeable income is less than proportional to the reduction of $K m_{1}$, since $\pi_{1}$ is smaller than unity. Graphically, this implies a smaller reduction of the intercept of the curve representing the pledgeable income. Because the pledgeable income decreases less with interstate banking following a bank capital crunch, we also have a smaller reduction in the amount of uninformed capital that can be attracted by firms. 
A similar mechanism is at work for the collateral squeeze. With unit banking, the reduction in pledgeable income is proportional to the reduction of $K f_{1}$. With interstate banking, by contrast, the reduction in pledgeable income is more than proportional to the reduction of $K f_{1}$, because the share of informed capital $\pi_{1}$ invested in state 1 - which depends on the amount of capital available in the two states - also decreases following a decrease of $K f_{1}$. Graphically, this implies a larger reduction of the intercept of the curve representing the pledgeable income. Because the pledgeable income decreases more with interstate banking following a collateral squeeze, we also have a larger reduction in the amount of uninformed capital that can be attracted by firms.

\section{Capital crunch: proof of proposition 1}

For the unit banking case, the derivative of $K u_{1}$ with respect to $K m_{1}$ is

Impact on the availability of uninformed capital

For the unit banking case, the derivative of $K u_{1}$ with respect to $K m_{1}$ is

$\frac{\partial K u_{1}^{u}}{\partial K m_{1}}=\frac{p_{H}(-b-c+R \cdot \Delta p)}{p_{H}(b+c-R \cdot \Delta p)+\Delta p \cdot \gamma}$

$\partial K u_{1}^{u} / \partial K m_{1}$ is positive. The numerator is positive because the positiveness of the payment promised to uninformed investors, $R m=K(R-(b+c) / \Delta p)>0$, implies $p_{H}(-b-c+R \cdot \Delta p)>0$. The denominator is also positive, because the return on uninformed capital $\gamma$ has to be larger than the pledgeable expected income $p_{H}(R-(b+c) / \Delta p)$ to have an interior solution for $K u_{1}$ (see HT, p. 682). For the interstate banking case, the derivative of $K u_{1}$ with respect to $K m_{1}$ is

$$
\frac{\partial K u_{1}^{i}}{\partial K m_{1}}=\frac{p_{H}(-b-c+R \cdot \Delta p)}{2\left(p_{H}(b+c-R \cdot \Delta p)+\Delta p \cdot \gamma\right)}
$$

under the above mentioned symmetry conditions. 
$\partial K u_{1}^{u} / \partial K m_{1}$ is twice as large as $\partial K u_{1}^{i} / \partial K m_{1}$

Impact on the availability of informed capital

For the unit banking case, the derivative of $K m_{1}$ with respect to itself is equal to unity.

For the interstate banking case, the quantity of informed capital attracted by firms in state 1 is equal to $\pi_{1}\left(K m_{1}+K m_{2}\right)$ with $\pi_{1}=\frac{K f_{1}}{K f_{1}+K f_{2}}$. The derivative of this quantity with respect to $K m_{1}$ is

$\frac{\partial \pi_{1}\left(K m_{1}+K m_{2}\right)}{\partial K m_{1}}=\frac{1}{2}$

under the above mentioned symmetry conditions.

$\partial \pi_{1}\left(K m_{1}+K m_{2}\right) / \partial K m_{1}$ is smaller than unity.

\section{Collateral squeeze: proof of proposition 2}

Impact on the availability of uninformed capital

For the unit banking case, the derivative of $K u_{1}$ with respect to $K f_{1}$ is

$\frac{\partial K u_{1}^{u}}{\partial K f_{1}}=\frac{p_{H}(-b-c+R \cdot \Delta p)}{p_{H}(b+c-R \cdot \Delta p)+\Delta p \cdot \gamma}$.

$\partial K u_{1}^{u} / \partial K f_{1}$ is positive.

For the interstate banking case, the derivative of $K u_{1}$ with respect to $K f_{1}$ is equal to

$$
\frac{\partial K u_{1}^{i}}{\partial K f_{1}}=\frac{p_{H}(-b-c+R \cdot \Delta p)\left(2 K f_{1}+K m_{1}\right)}{2 K f_{1}\left(p_{H}(b+c-R \cdot \Delta p)+\Delta p \cdot \gamma\right)}
$$


under the symmetry conditions $K f_{1}=K f_{2}$ and $K m_{1}=K m_{2}$ at initial values. $\partial K u_{1}^{i} / \partial K f_{1}$ is positive.

The difference between the two derivatives is

$\frac{\partial K u_{2}^{i}}{\partial K f_{1}}-\frac{\partial K u_{2}^{u}}{\partial K f_{1}}=\frac{p_{H}(-b-c+R \cdot \Delta p) K m_{1}}{2 K f_{1}\left(p_{H}(b+c-R \cdot \Delta p)+\Delta p \cdot \gamma\right)}$

$\partial K u_{2}^{i} / \partial K f_{1}-\partial K u_{2}^{u} / \partial K f_{1}$ is positive.

Impact on the availability of uninformed capital

For the unit banking case, the derivative of $K m_{1}$ with respect to $K f_{1}$ is equal to zero, since $K m_{1}$ is independent of $K f_{1}$.

For the interstate banking case, the quantity of informed capital attracted by firms in state 1 is equal to $\pi_{1}\left(K m_{1}+K m_{2}\right)$ with $\pi_{1}=\frac{K f_{1}}{K f_{1}+K f_{2}}$. The derivative of this quantity with respect to $K f_{1}$ is $\frac{\partial \pi_{1}\left(K m_{1}+K m_{2}\right)}{\partial K f_{1}}=\frac{K m_{1}}{2 K f_{1}}$

under the above mentioned symmetry conditions.

$\partial \pi_{1}\left(K m_{1}+K m_{2}\right) / \partial K m_{1}$ is larger than zero. 
Table 1

State-Specific Business Volatility Has Fallen as Integration Has Increased

We decompose employment growth and personal income growth, for which we have a longer time series, in state $j$ in year $t$ as follows:

$$
\boldsymbol{Y}_{j, t}=a_{j}+b_{t}+e_{j, t}
$$

Where $a_{j}$ is the state-specific average growth rate over the period; $b_{t}$ is the aggregate shock to growth at time $t ; e_{j, t}$ is the time $t$ shock to growth that is specific to circumstances in state $j$. We estimate these regressions separately over 5 non-overlapping periods (i.e. the state fixed effect is allowed to be different over each of the 5 periods).

\section{Panel A: Employment Growth}

\begin{tabular}{lccc}
\hline & & $\begin{array}{c}\text { Root MSE Of } \\
\text { State-Specific } \\
\text { Shock to } \\
\text { Employment } \\
\text { Growth }\left(\mathbf{e}_{\mathrm{j}, \mathrm{t}}\right)\end{array}$ & $\begin{array}{c}\text { Average Bank } \\
\text { Integration }\end{array}$ \\
\cline { 3 - 4 } $1977-1981$ & Pre-Interstate Banking & $2.4 \%$ & $14 \%$ \\
$1982-1985$ & Transition & $2.2 \%$ & $26 \%$ \\
$1986-1989$ & Transition & $1.9 \%$ & $46 \%$ \\
$1990-1993$ & Transition & $1.6 \%$ & $53 \%$ \\
$1994-1997$ & Post-Interstate Banking & $1.1 \%$ & $59 \%$ \\
\hline
\end{tabular}

Panel B: Personal Income Growth

Period

1962-1966

1967-1971

1972-1976

1977-1981

1982-1985

1986-1989

1990-1993

1994-1997

1998-2000

\section{Root MSE Of \\ State-Specific Shock to Personal Income Growth}

$\left(\mathbf{e}_{\mathrm{j}, \mathrm{t}}\right)$

$3.5 \%$

$2.0 \%$

$3.9 \%$

$3.0 \%$

$2.0 \%$

$1.9 \%$

$1.3 \%$

$1.5 \%$

$1.0 \%$

Pre-Interstate Banking
Pre-Interstate Banking
Pre-Interstate Banking
Pre-Interstate Banking
Transition
Transition
Transition

Post-Interstate Banking
Average Bank Integration
Low
Low
Low
$14 \%$
$26 \%$
$46 \%$
$53 \%$
$59 \%$

Post-Interstate Banking

*Integration equals the share of banking assets in a state owned by a multi-state bank holding company. We do not have the data to construct this integration measure before 1976 or after 1994. (The figure for the 1994-1997 period is the average for 1994.) Note that interstate integration continued after 1994 due to cross-state consolidation such as the merger of Bank of America (a west coast bank holding company) and NationsBank (an southeast bank holding company) in 1998. We cannot construct our measure of integration after 1994 because bank holding companies began to consolidate their holding of bank assets across state lines in 1995. We believe that the integration figure would be higher than 59\% during the last years in this table, however. 
Table 2

Bank Integration, Business Volatility and State Labor Share: Summary Statistics

Statistics calculated using state-year observations. Integration is the share of bank assets in each state held by banks with offices out of the state. Growth is the annual growth in employment or small firm employment, where a firm is defined as small if it has fewer than 20 employees. Volatility is based on the deviation in the annual growth of total employment or small firm employment (firms with fewer than 20 employees) from state and national means. To construct this deviation for small firms, we also control for employment growth at large firms (firms with more than 250 employees).

\section{A. Integration}

\section{B. Employment}

Employment Growth

Squared Deviation from Expected Growth

Log of Squared Deviation from Expected Growth

Absolute Value of Deviation from Expected Growth

C. Small-Firm Employment (<20 Employees)

Employment Growth

Squared Deviation from Expected Growth

Log of Squared Deviation from Expected Growth

Absolute Value of Deviation from Expected Growth

\section{Labor Shares}

Mining

Construction

Manufacturing

Transportation

Trade

Finance

Services

Government

Labor Share HHI (Sum of Squared Shares)

$\begin{array}{ccc}\underline{\mathbf{N}} & \frac{\text { Mean }}{0.34} & \begin{array}{l}\text { Standard } \\ \text { Deviation }\end{array} \\ 931 & & \frac{0.28}{}\end{array}$

$\begin{array}{ccc}931 & 0.023 & 0.023 \\ 931 & 0.0003 & 0.0007 \\ 931 & -9.66 & 2.40 \\ 931 & 0.013 & 0.012\end{array}$

$\begin{array}{lcc}823 & 0.023 & 0.026 \\ 823 & 0.0004 & 0.0008 \\ 823 & -9.58 & 2.46 \\ 823 & 0.014 & 0.013\end{array}$

$\begin{array}{lll}870 & 0.013 & 0.018\end{array}$

$\begin{array}{lll}870 & 0.048 & 0.014\end{array}$

$870 \quad 0.194 \quad 0.112$

$\begin{array}{lll}870 & 0.055 & 0.012\end{array}$

$\begin{array}{lll}870 & 0.229 & 0.038\end{array}$

$870 \quad 0.054 \quad 0.013$

$\begin{array}{lll}870 & 0.221 & 0.060\end{array}$

$\begin{array}{lll}870 & 0.188 & 0.048\end{array}$

$\begin{array}{lll}870 & 0.203 & 0.058\end{array}$ 
Table 3

Volatility of State Employment Growth Falls as Bank Integration Increases

Regressions are based on a panel of state-year observations. Integration is the share of bank assets in each state held by banks with offices out of the state. Growth is the annual growth in employment. Volatility is based on the deviation in the annual growth of total employment from state and national means.

Coefficients estimated with state-year observations over 1976-94 (standard errors in parenthesis). All models include state and year fixed effects.

\begin{tabular}{|c|c|c|c|c|c|c|}
\hline \multirow[b]{2}{*}{$\begin{array}{l}\text { Dependent } \\
\text { Variable: }\end{array}$} & \multicolumn{3}{|c|}{ Fixed Effects Regressions } & \multicolumn{3}{|c|}{ IV Regressions } \\
\hline & $\begin{array}{c}\text { Squared } \\
\text { Deviation } \\
\text { from } \\
\text { Expected } \\
\text { Growth }\end{array}$ & $\begin{array}{c}\text { Log of } \\
\text { Squared } \\
\text { Deviation } \\
\text { from } \\
\text { Expected } \\
\text { Growth } \\
\end{array}$ & $\begin{array}{c}\text { Absolute } \\
\text { Value of } \\
\text { Deviation } \\
\text { from } \\
\text { Expected } \\
\text { Growth } \\
\end{array}$ & $\begin{array}{c}\text { Squared } \\
\text { Deviation } \\
\text { from } \\
\text { Expected } \\
\text { Growth }\end{array}$ & $\begin{array}{c}\text { Log of } \\
\text { Squared } \\
\text { Deviation } \\
\text { from } \\
\text { Expected } \\
\text { Growth } \\
\end{array}$ & $\begin{array}{c}\text { Absolute } \\
\text { Value of } \\
\text { Deviation } \\
\text { from } \\
\text { Expected } \\
\text { Growth }\end{array}$ \\
\hline Integration & $\begin{array}{c}-0.0006^{* *} \\
(0.0002)\end{array}$ & $\begin{array}{c}-1.44 * * \\
(0.65)\end{array}$ & $\begin{array}{c}-0.013 * * \\
(0.003)\end{array}$ & $\begin{array}{l}-0.002 * * \\
(0.0005)\end{array}$ & $\begin{array}{c}-1.90 \\
(1.84)\end{array}$ & $\begin{array}{c}-0.036^{* * *} \\
(0.009)\end{array}$ \\
\hline \multicolumn{7}{|l|}{ Labor Shares: } \\
\hline Mining & $\begin{array}{c}0.002 \\
(0.004)\end{array}$ & $\begin{array}{c}30.7 * \\
(17.1)\end{array}$ & $\begin{array}{l}0.13^{*} \\
(0.08)\end{array}$ & $\begin{array}{l}0.010^{*} \\
(0.005)\end{array}$ & $\begin{array}{l}32.8^{*} \\
(18.9)\end{array}$ & $\begin{array}{c}0.24 * * \\
(0.09)\end{array}$ \\
\hline Construction & $\begin{array}{c}0.012 * * \\
(0.003)\end{array}$ & $\begin{array}{l}22.8^{*} \\
(12.7)\end{array}$ & $\begin{array}{l}0.19 * * \\
(0.06)\end{array}$ & $\begin{array}{c}0.018^{* * *} \\
(0.004)\end{array}$ & $\begin{array}{l}24.6^{*} \\
(14.5)\end{array}$ & $\begin{array}{l}0.28 * * \\
(0.07)\end{array}$ \\
\hline Manufacturing & $\begin{array}{c}-0.008 * * \\
(0.004)\end{array}$ & $\begin{array}{l}-23.8^{*} \\
(13.4)\end{array}$ & $\begin{array}{c}-0.16^{* * *} \\
(0.06)\end{array}$ & $\begin{array}{c}-0.002 \\
(0.004)\end{array}$ & $\begin{array}{l}-22.3 \\
(14.6)\end{array}$ & $\begin{array}{l}-0.09 \\
(0.07)\end{array}$ \\
\hline Transportation & $\begin{array}{l}-0.012 \\
(0.010)\end{array}$ & $\begin{array}{c}13.0 \\
(38.7)\end{array}$ & $\begin{array}{l}-0.13 \\
(0.18)\end{array}$ & $\begin{array}{l}-0.003 \\
(0.011)\end{array}$ & $\begin{array}{c}15.6 \\
(39.9)\end{array}$ & $\begin{array}{c}0.01 \\
(0.20)\end{array}$ \\
\hline Trade & $\begin{array}{l}-0.009 \\
(0.005)\end{array}$ & $\begin{array}{l}-19.9 \\
(20.6)\end{array}$ & $\begin{array}{l}-0.13 \\
(0.10)\end{array}$ & $\begin{array}{c}0.008 \\
(0.008)\end{array}$ & $\begin{array}{l}-15.3 \\
(27.0)\end{array}$ & $\begin{array}{c}0.11 \\
(0.13)\end{array}$ \\
\hline Finance & $\begin{array}{l}-0.015 \\
(0.010)\end{array}$ & $\begin{array}{l}-35.8 \\
(36.1)\end{array}$ & $\begin{array}{l}-0.26 \\
(0.17)\end{array}$ & $\begin{array}{l}-0.019^{*} \\
(0.010)\end{array}$ & $\begin{array}{l}-36.9 \\
(36.4)\end{array}$ & $\begin{array}{l}-0.32^{*} \\
(0.18)\end{array}$ \\
\hline Services & $\begin{array}{c}0.001 \\
(0.004)\end{array}$ & $\begin{array}{l}-16.6 \\
(17.0)\end{array}$ & $\begin{array}{l}-0.06 \\
(0.08)\end{array}$ & $\begin{array}{l}0.010^{*} \\
(0.005)\end{array}$ & $\begin{array}{l}-14.1 \\
(19.6)\end{array}$ & $\begin{array}{c}0.07 \\
(0.10)\end{array}$ \\
\hline Government & & & -Omitted & egory---.-. & & \\
\hline $\begin{array}{l}\text { Labor Share } \\
\text { HHI }\end{array}$ & $\begin{array}{c}-0.002 \\
(0.005)\end{array}$ & $\begin{array}{c}27.8 \\
(18.7)\end{array}$ & $\begin{array}{c}0.08 \\
(0.09)\end{array}$ & $\begin{array}{l}-0.002 \\
(0.005)\end{array}$ & $\begin{array}{c}27.7 \\
(18.7)\end{array}$ & $\begin{array}{c}0.08 \\
(0.09)\end{array}$ \\
\hline $\mathrm{N}$ & 870 & 870 & 870 & 870 & 870 & 870 \\
\hline $\mathrm{R}^{2}$ & 0.1093 & 0.0874 & 0.1339 & 0.1179 & 0.0831 & 0.1328 \\
\hline
\end{tabular}

*significant at $10 \%$ level. ** significant at $5 \%$ level 
Table 4

Small Firm Employment Growth Volatility Declines As Bank Integration Increases

Regressions are based on a panel of state-year observations. Integration is the share of bank assets in each state held by banks with offices out of the state. Growth is the annual growth in employment at small establishments, defined as establishments with fewer than 20 employees. Volatility is based on the deviation in the annual growth of total employment from state and national means; in addition, we control for growth at large establishments (defined as those with more than 250 employees). Coefficients estimated with state-year observations over 1976-94 (standard errors in parenthesis). All models include state and year fixed effects.

\begin{tabular}{|c|c|c|c|c|c|c|}
\hline \multirow[b]{2}{*}{$\begin{array}{l}\text { Dependent } \\
\text { Variable: }\end{array}$} & \multicolumn{3}{|c|}{ Fixed Effects Regressions } & \multicolumn{3}{|c|}{ IV Regressions } \\
\hline & $\begin{array}{c}\text { Squared } \\
\text { Deviation } \\
\text { from } \\
\text { Expected } \\
\text { Growth }\end{array}$ & $\begin{array}{c}\text { Log of } \\
\text { Squared } \\
\text { Deviation } \\
\text { from } \\
\text { Expected } \\
\text { Growth }\end{array}$ & $\begin{array}{c}\text { Absolute } \\
\text { Value of } \\
\text { Deviation } \\
\text { from } \\
\text { Expected } \\
\text { Growth }\end{array}$ & $\begin{array}{c}\text { Squared } \\
\text { Deviation } \\
\text { from } \\
\text { Expected } \\
\text { Growth }\end{array}$ & $\begin{array}{c}\text { Log of } \\
\text { Squared } \\
\text { Deviation } \\
\text { from } \\
\text { Expected } \\
\text { Growth }\end{array}$ & $\begin{array}{c}\text { Absolute } \\
\text { Value of } \\
\text { Deviation } \\
\text { from } \\
\text { Expected } \\
\text { Growth }\end{array}$ \\
\hline Integration & $\begin{array}{c}-0.0003 \\
(0.0002)\end{array}$ & $\begin{array}{c}-1.55^{* *} \\
(0.71)\end{array}$ & $\begin{array}{c}-0.009 * * \\
(0.004)\end{array}$ & $\begin{array}{c}-0.003 * * \\
(0.0007)\end{array}$ & $\begin{array}{c}-4.66^{* *} \\
(2.19)\end{array}$ & $\begin{array}{c}-0.040^{* *} \\
(0.011)\end{array}$ \\
\hline Labor Shares: & & & & & & \\
\hline Mining & $\begin{array}{c}-0.018 * * \\
(0.006)\end{array}$ & $\begin{array}{c}29.3 \\
(20.8)\end{array}$ & $\begin{array}{l}-0.12 \\
(0.10)\end{array}$ & $\begin{array}{l}-0.008 \\
(0.008)\end{array}$ & $\begin{array}{l}43.5^{*} \\
(23.1)\end{array}$ & $\begin{array}{c}0.02 \\
(0.12)\end{array}$ \\
\hline Construction & $\begin{array}{c}0.025 * * \\
(0.005)\end{array}$ & $\begin{array}{l}42.8 * * \\
(17.2)\end{array}$ & $\begin{array}{c}0.33 * * \\
(0.09)\end{array}$ & $\begin{array}{c}0.034 * * \\
(0.006)\end{array}$ & $\begin{array}{c}55.4 * * \\
(19.3)\end{array}$ & $\begin{array}{c}0.45^{* *} \\
(0.10)\end{array}$ \\
\hline Manufacturing & $\begin{array}{c}-0.016 * * \\
(0.005)\end{array}$ & $\begin{array}{c}-7.1 \\
(16.4)\end{array}$ & $\begin{array}{c}-0.20^{* *} \\
(0.08)\end{array}$ & $\begin{array}{l}-0.007 \\
(0.006)\end{array}$ & $\begin{array}{c}4.7 \\
(18.3)\end{array}$ & $\begin{array}{l}-0.08 \\
(0.09)\end{array}$ \\
\hline Transportation & $\begin{array}{c}-0.033 * * \\
(0.008)\end{array}$ & $\begin{array}{c}28.3 \\
(45.1)\end{array}$ & $\begin{array}{l}-0.25 \\
(0.22)\end{array}$ & $\begin{array}{l}-0.016 \\
(0.016)\end{array}$ & $\begin{array}{c}52.0 \\
(48.3)\end{array}$ & $\begin{array}{l}-0.01 \\
(0.25)\end{array}$ \\
\hline Trade & $\begin{array}{l}-0.014 \\
(0.013)\end{array}$ & $\begin{array}{l}-3.5 \\
(24.9)\end{array}$ & $\begin{array}{l}-0.14 \\
(0.12)\end{array}$ & $\begin{array}{c}0.012 \\
(0.011)\end{array}$ & $\begin{array}{c}32.2 \\
(34.6)\end{array}$ & $\begin{array}{c}0.21 \\
(0.18)\end{array}$ \\
\hline Finance & $\begin{array}{l}-0.014 \\
(0.013)\end{array}$ & $\begin{array}{c}39.9 \\
(41.7)\end{array}$ & $\begin{array}{l}-0.09 \\
(0.10)\end{array}$ & $\begin{array}{l}-0.023 \\
(0.014)\end{array}$ & $\begin{array}{c}28.2 \\
(43.0)\end{array}$ & $\begin{array}{l}-0.20 \\
(0.22)\end{array}$ \\
\hline Services & $\begin{array}{l}-0.002 \\
(0.006)\end{array}$ & $\begin{array}{l}-11.4 \\
(21.1)\end{array}$ & $\begin{array}{l}-0.08 \\
(0.10)\end{array}$ & $\begin{array}{c}0.011 \\
(0.008)\end{array}$ & $\begin{array}{c}7.4 \\
(25.9)\end{array}$ & $\begin{array}{c}0.11 \\
(0.13)\end{array}$ \\
\hline $\begin{array}{l}\text { Government } \\
\text { Labor Share } \\
\text { HHI }\end{array}$ & $\begin{array}{c}0.002 \\
(0.008)\end{array}$ & $\begin{array}{l}25.7 \\
(25.5)\end{array}$ & $\begin{array}{c}- \text { Omitted } \\
0.07 \\
(0.13)\end{array}$ & $\begin{array}{c}\text { egory--.- } \\
0.001 \\
(0.008)\end{array}$ & $\begin{array}{c}22.9 \\
(25.9)\end{array}$ & $\begin{array}{c}0.04 \\
(0.13)\end{array}$ \\
\hline $\mathrm{N}$ & 778 & 778 & 778 & 778 & 778 & 778 \\
\hline $\mathrm{R}^{2}$ & 0.1765 & 0.1012 & 0.1731 & 0.1903 & 0.1008 & 0.1802 \\
\hline
\end{tabular}


Table 5, Panel A

Employment Growth Volatility Falls with Banking Integration,

Particularly in States with Highly Concentrated Economies

Regressions are based on a panel of state-year observations. Integration is the share of bank assets in each state held by banks with offices out of the state. Growth is the annual growth in employment. Volatility is based on the deviation in the annual growth of total employment from state and national means.

Coefficients estimated with state-year observations over 1976-94 (standard errors in parenthesis). All models include state and year fixed effects.

\begin{tabular}{|c|c|c|c|c|c|c|}
\hline \multirow[b]{2}{*}{$\begin{array}{l}\text { Dependent } \\
\text { Variable: }\end{array}$} & \multicolumn{3}{|c|}{ Fixed Effects Regressions } & \multicolumn{3}{|c|}{ IV Regressions } \\
\hline & $\begin{array}{c}\text { Squared } \\
\text { Deviation } \\
\text { from } \\
\text { Expected } \\
\text { Growth }\end{array}$ & $\begin{array}{c}\text { Log of } \\
\text { Squared } \\
\text { Deviation } \\
\text { from } \\
\text { Expected } \\
\text { Growth }\end{array}$ & $\begin{array}{c}\text { Absolute } \\
\text { Value of } \\
\text { Deviation } \\
\text { from } \\
\text { Expected } \\
\text { Growth }\end{array}$ & $\begin{array}{c}\text { Squared } \\
\text { Deviation } \\
\text { from } \\
\text { Expected } \\
\text { Growth }\end{array}$ & $\begin{array}{c}\text { Log of } \\
\text { Squared } \\
\text { Deviation } \\
\text { from } \\
\text { Expected } \\
\text { Growth }\end{array}$ & $\begin{array}{c}\text { Absolute } \\
\text { Value of } \\
\text { Deviation } \\
\text { from } \\
\text { Expected } \\
\text { Growth }\end{array}$ \\
\hline Integration & $\begin{array}{c}0.0012 \\
(0.0005)\end{array}$ & $\begin{array}{c}0.87 \\
(1.99)\end{array}$ & $\begin{array}{c}0.016^{*} \\
(0.009)\end{array}$ & $\begin{array}{c}-0.0004 \\
(0.0009)\end{array}$ & $\begin{array}{c}3.20 \\
(1.84)\end{array}$ & $\begin{array}{c}0.003 \\
(0.016)\end{array}$ \\
\hline $\begin{array}{l}\text { Integration* } \\
\text { Labor Share } \\
\text { HHI }\end{array}$ & $\begin{array}{c}-0.008^{* *} \\
(0.002)\end{array}$ & $\begin{array}{l}-11.24 \\
(9.13)\end{array}$ & $\begin{array}{c}-0.137 * * \\
(0.043)\end{array}$ & $\begin{array}{c}-0.009 * * \\
(0.004)\end{array}$ & $\begin{array}{l}-25.01^{*} \\
(14.78)\end{array}$ & $\begin{array}{c}-0.192 * * \\
(0.070)\end{array}$ \\
\hline Labor Shares: & & & & & & \\
\hline$\overline{\text { Mining }}$ & $\begin{array}{l}-0.001 \\
(0.005)\end{array}$ & $\begin{array}{c}27.8 \\
(17.2)\end{array}$ & $\begin{array}{c}0.10 \\
(0.08)\end{array}$ & $\begin{array}{l}0.010^{*} \\
(0.005)\end{array}$ & $\begin{array}{l}31.8^{*} \\
(18.8)\end{array}$ & $\begin{array}{c}0.23 * * \\
(0.09)\end{array}$ \\
\hline Construction & $\begin{array}{c}0.010 * * \\
(0.003)\end{array}$ & $\begin{array}{l}21.3^{*} \\
(12.7)\end{array}$ & $\begin{array}{l}0.17 * * \\
(0.06)\end{array}$ & $\begin{array}{c}0.017 * * \\
(0.004)\end{array}$ & $\begin{array}{c}22.2 \\
(14.6)\end{array}$ & $\begin{array}{l}0.26 * * \\
(0.07)\end{array}$ \\
\hline Manufacturing & $\begin{array}{c}-0.010 * * \\
(0.004)\end{array}$ & $\begin{array}{l}-26.2 * \\
(13.6)\end{array}$ & $\begin{array}{c}-0.19 * * \\
(0.06)\end{array}$ & $\begin{array}{l}-0.003 \\
(0.004)\end{array}$ & $\begin{array}{l}-24.2^{*} \\
(14.6)\end{array}$ & $\begin{array}{l}-0.10 \\
(0.07)\end{array}$ \\
\hline Transportation & $\begin{array}{l}-0.013 \\
(0.010)\end{array}$ & $\begin{array}{c}11.3 \\
(38.7)\end{array}$ & $\begin{array}{l}-0.15 \\
(0.18)\end{array}$ & $\begin{array}{l}-0.005 \\
(0.010)\end{array}$ & $\begin{array}{c}9.0 \\
(40.1)\end{array}$ & $\begin{array}{l}-0.05 \\
(0.19)\end{array}$ \\
\hline Trade & $\begin{array}{c}-0.013 * * \\
(0.005)\end{array}$ & $\begin{array}{l}-25.1 \\
(21.0)\end{array}$ & $\begin{array}{l}-0.20^{*} \\
(0.10)\end{array}$ & $\begin{array}{c}0.005 \\
(0.007)\end{array}$ & $\begin{array}{l}-23.9 \\
(27.5)\end{array}$ & $\begin{array}{c}0.04 \\
(0.13)\end{array}$ \\
\hline Finance & $\begin{array}{l}-0.014 \\
(0.009)\end{array}$ & $\begin{array}{l}-34.2 \\
(36.1)\end{array}$ & $\begin{array}{l}-0.24 \\
(0.17)\end{array}$ & $\begin{array}{c}-0.019 * * \\
(0.010)\end{array}$ & $\begin{array}{l}-37.3 \\
(36.4)\end{array}$ & $\begin{array}{l}-0.32 * \\
(0.17)\end{array}$ \\
\hline Services & $\begin{array}{l}-0.006 \\
(0.005)\end{array}$ & $\begin{array}{l}-25.6 \\
(18.5)\end{array}$ & $\begin{array}{l}-0.17^{*} \\
(0.09)\end{array}$ & $\begin{array}{c}0.007 \\
(0.005)\end{array}$ & $\begin{array}{l}-21.7 \\
(20.1)\end{array}$ & $\begin{array}{c}0.01 \\
(0.09)\end{array}$ \\
\hline $\begin{array}{l}\text { Government } \\
\text { Labor Share } \\
\text { HHI }\end{array}$ & $\begin{array}{c}0.001 \\
(0.005) \\
\end{array}$ & $\begin{array}{c}30.9 \\
(18.9) \\
\end{array}$ & $\begin{array}{c}\text { Omitted } \\
0.12 \\
(0.09) \\
\end{array}$ & $\begin{array}{c}\text { egory-- } \\
-0.002 \\
(0.005) \\
\end{array}$ & $\begin{array}{c}27.2 \\
(18.7)\end{array}$ & $\begin{array}{c}0.08 \\
(0.09) \\
\end{array}$ \\
\hline $\begin{array}{l}\mathrm{N} \\
\mathrm{R}^{2}\end{array}$ & $\begin{array}{c}870 \\
0.1231\end{array}$ & $\begin{array}{c}870 \\
0.0891\end{array}$ & $\begin{array}{c}870 \\
0.1448\end{array}$ & $\begin{array}{c}870 \\
0.1263\end{array}$ & $\begin{array}{c}870 \\
0.0862\end{array}$ & $\begin{array}{c}870 \\
0.1424\end{array}$ \\
\hline
\end{tabular}

*significant at $10 \%$ level. $* *$ significant at $5 \%$ level 
Table 5, Panel B

Employment Growth Volatility Falls with Banking Integration,

Particularly in Small States

Regressions are based on a panel of state-year observations. Integration is the share of bank assets in each state held by banks with offices out of the state. Growth is the annual growth in employment. Volatility is based on the deviation in the annual growth of total employment from state and national means.

Coefficients estimated with state-year observations over 1976-94 (standard errors in parenthesis). All models include state and year fixed effects and are estimated with IV.

\begin{tabular}{|c|c|c|c|c|c|c|}
\hline \multirow[b]{2}{*}{$\begin{array}{l}\text { Dependent } \\
\text { Variable: }\end{array}$} & \multicolumn{3}{|c|}{$\begin{array}{c}\text { Small States } \\
(1975 \text { Income }<\text { Median }) \\
\end{array}$} & \multicolumn{3}{|c|}{$\begin{array}{c}\text { Large States } \\
(1975 \text { Income }>=\text { Median })\end{array}$} \\
\hline & $\begin{array}{c}\text { Squared } \\
\text { Deviation } \\
\text { from } \\
\text { Expected } \\
\text { Growth }\end{array}$ & $\begin{array}{c}\text { Log of } \\
\text { Squared } \\
\text { Deviation } \\
\text { from } \\
\text { Expected } \\
\text { Growth }\end{array}$ & $\begin{array}{c}\text { Absolute } \\
\text { Value of } \\
\text { Deviation } \\
\text { from } \\
\text { Expected } \\
\text { Growth }\end{array}$ & $\begin{array}{c}\text { Squared } \\
\text { Deviation } \\
\text { from } \\
\text { Expected } \\
\text { Growth }\end{array}$ & $\begin{array}{c}\text { Log of } \\
\text { Squared } \\
\text { Deviation } \\
\text { from } \\
\text { Expected } \\
\text { Growth }\end{array}$ & $\begin{array}{c}\text { Absolute } \\
\text { Value of } \\
\text { Deviation } \\
\text { from } \\
\text { Expected } \\
\text { Growth }\end{array}$ \\
\hline Integration & $\begin{array}{l}-0.0021 * * \\
(0.0007)\end{array}$ & $\begin{array}{l}-1.95 \\
(2.00)\end{array}$ & $\begin{array}{c}-0.032 * * \\
(0.011)\end{array}$ & $\begin{array}{l}-0.0009 \\
(0.0007)\end{array}$ & $\begin{array}{c}2.39 \\
(4.21)\end{array}$ & $\begin{array}{l}-0.009 \\
(0.016)\end{array}$ \\
\hline \multicolumn{7}{|l|}{ Labor Shares: } \\
\hline Mining & $\begin{array}{c}0.007 \\
(0.006)\end{array}$ & $\begin{array}{c}19.83 \\
(19.59)\end{array}$ & $\begin{array}{l}0.191^{*} \\
(0.107)\end{array}$ & $\begin{array}{l}0.018^{*} \\
(0.010)\end{array}$ & $\begin{array}{c}18.93 \\
(60.56)\end{array}$ & $\begin{array}{c}0.296 \\
(0.233)\end{array}$ \\
\hline Construction & $\begin{array}{c}0.017 * * \\
(0.005)\end{array}$ & $\begin{array}{c}10.56 \\
(15.38)\end{array}$ & $\begin{array}{c}0.228 * * \\
(0.084)\end{array}$ & $\begin{array}{l}-0.005 \\
(0.005)\end{array}$ & $\begin{array}{l}10.85 \\
(32.02)\end{array}$ & $\begin{array}{l}-0.054 \\
(0.123)\end{array}$ \\
\hline Manufacturing & $\begin{array}{c}-0.013 * * \\
(0.006)\end{array}$ & $\begin{array}{c}-51.33 * * \\
(17.36)\end{array}$ & $\begin{array}{c}-0.295 * * \\
(0.095)\end{array}$ & $\begin{array}{l}0.006 \\
(0.007)\end{array}$ & $\begin{array}{l}-17.10 \\
(46.56)\end{array}$ & $\begin{array}{c}0.030 \\
(0.180)\end{array}$ \\
\hline Transportation & $\begin{array}{l}-0.026 \\
(0.017)\end{array}$ & $\begin{array}{c}-102.08 * * \\
(48.55)\end{array}$ & $\begin{array}{l}-0.662 * * \\
(0.265)\end{array}$ & $\begin{array}{c}0.039 * * \\
(0.012)\end{array}$ & $\begin{array}{l}288.33^{* *} \\
(77.87)\end{array}$ & $\begin{array}{l}1.270^{* * *} \\
(0.300)\end{array}$ \\
\hline Trade & $\begin{array}{l}-0.012 \\
(0.010)\end{array}$ & $\begin{array}{l}-63.73 * * \\
(28.63)\end{array}$ & $\begin{array}{l}-0.302 * \\
(0.156)\end{array}$ & $\begin{array}{l}0.027^{*} \\
(0.014)\end{array}$ & $\begin{array}{c}13.26 \\
(88.16)\end{array}$ & $\begin{array}{c}0.415 \\
(0.339)\end{array}$ \\
\hline Finance & $\begin{array}{l}-0.027 * \\
(0.016)\end{array}$ & $\begin{array}{l}-52.50 \\
(45.02)\end{array}$ & $\begin{array}{l}-0.474^{*} \\
(0.246)\end{array}$ & $\begin{array}{l}0.042^{* *} \\
(0.011)\end{array}$ & $\begin{array}{l}112.85 \\
(70.77)\end{array}$ & $\begin{array}{l}0.888^{* * *} \\
(0.272)\end{array}$ \\
\hline Services & $\begin{array}{c}0.005 \\
(0.007)\end{array}$ & $\begin{array}{l}-27.99 \\
(19.50)\end{array}$ & $\begin{array}{l}-0.019 \\
(0.107)\end{array}$ & $\begin{array}{l}-0.005 \\
(0.012)\end{array}$ & $\begin{array}{l}-101.56 \\
(75.14)\end{array}$ & $\begin{array}{l}-0.334 \\
(0.290)\end{array}$ \\
\hline $\begin{array}{l}\text { Government } \\
\text { Labor Share } \\
\text { HHI }\end{array}$ & $\begin{array}{c}0.001 \\
(0.007)\end{array}$ & $\begin{array}{l}24.01 \\
(20.47)\end{array}$ & $\begin{array}{c}- \text {-Omitted } \\
0.126 \\
(0.111)\end{array}$ & $\begin{array}{c}\text { egory--.-. } \\
0.015 \\
(0.010)\end{array}$ & $\begin{array}{c}158.02 * * \\
(60.781)\end{array}$ & $\begin{array}{c}0.555^{* *} \\
(0.233)\end{array}$ \\
\hline $\mathrm{N}$ & 432 & 432 & 432 & 438 & 438 & 438 \\
\hline $\mathrm{R}^{2}$ & 0.1134 & 0.1579 & 0.1812 & 0.1995 & 0.0795 & 0.2071 \\
\hline
\end{tabular}

*significant at $10 \%$ level. $* *$ significant at $5 \%$ level 
Table 6

How Integration affects the Correlation between Employment, Loan Growth and Changes in Bank Capital and Housing Prices

Reported are fixed effects regression coefficients and standards errors (in parenthesis) estimated for panel of 48 states and D.C. The dependent variable and associated estimation periods are indicated at the top of each column. Bank capital growth is the annual growth rate of total capital held by all banks headquartered in each state. Growth in housing prices is the ratio of Freddic Mac's index of housing prices in the state/year (fourth quarter) to that housing price index in the preceding year. Integration is the share of bank assets in each state held by banks with offices out of the state. All regressions include state and year fixed effects (not reported).

Panel A: Employment Growth

\begin{tabular}{|c|c|c|}
\hline Dependent variables: & $\frac{\text { Employment }}{\text { growth }}$ & $\underline{\underline{\text { Small-firm }}} \underline{\underline{\text { employment growth }}}$ \\
\hline Bank Capital Growth & $\begin{array}{l}0.136 * * \\
(0.014)\end{array}$ & $\begin{array}{l}0.177 * * \\
(0.015)\end{array}$ \\
\hline Growth in Housing Price & $\begin{array}{l}0.047 * * \\
(0.011)\end{array}$ & $\begin{array}{l}0.046 * * \\
(0.012)\end{array}$ \\
\hline Integration & $\begin{array}{l}0.101 * * \\
(0.002)\end{array}$ & $\begin{array}{l}0.126^{* *} \\
(0.035)\end{array}$ \\
\hline $\begin{array}{l}\text { Bank Capital Growth } x \\
\text { Integration }\end{array}$ & $\begin{array}{l}-0.167 * * \\
(0.021)\end{array}$ & $\begin{array}{l}-0.213 * * \\
(0.026)\end{array}$ \\
\hline $\begin{array}{l}\text { Growth in Housing Prices } \mathrm{x} \\
\text { Integration }\end{array}$ & $\begin{array}{l}0.079 * * \\
(0.026)\end{array}$ & $\begin{array}{l}0.107 * * \\
(0.029)\end{array}$ \\
\hline $\mathrm{R}$ & $\begin{array}{l}0.601 \\
882\end{array}$ & $\begin{array}{l}0.665 \\
823\end{array}$ \\
\hline
\end{tabular}

\section{Panel B: Loan Growth}

Dependent variables:

Growth in Business Loans (C\&I+Commercial Real Estate)

$\underline{\text { Total Loan Growth }}$

\begin{tabular}{lll}
\cline { 2 - 2 } Bank Capital Growth & $0.672 * *$ & $0.649 * *$ \\
& $(0.076)$ & $(0.070)$ \\
Growth in Housing Prices & $0.142^{* *}$ & $0.127 * *$ \\
& $(0.061)$ & $(0.056)$ \\
Integration & -0.094 & -0.141 \\
& $(0.181)$ & $(0.166)$ \\
Bank Capital Growth $\mathrm{x}$ & $-0.521^{* *}$ & $-0.252^{* *}$ \\
Integration & $(0.116)$ & $(0.106)$ \\
Growth in Housing Prices x & $0.647 * *$ & $0.390 * *$ \\
Integration & $(0.143)$ & $(0.131)$ \\
\hline $\mathrm{R}^{2}$ & 0.508 & 0.482 \\
$\mathrm{~N}$ & 882 & 882
\end{tabular}

\footnotetext{
*significant at $10 \%$ level. ** significant at $5 \%$ level
} 


\section{Percent of Bank Assets in a State Held by Out-of-State Bank Holding Companies*}
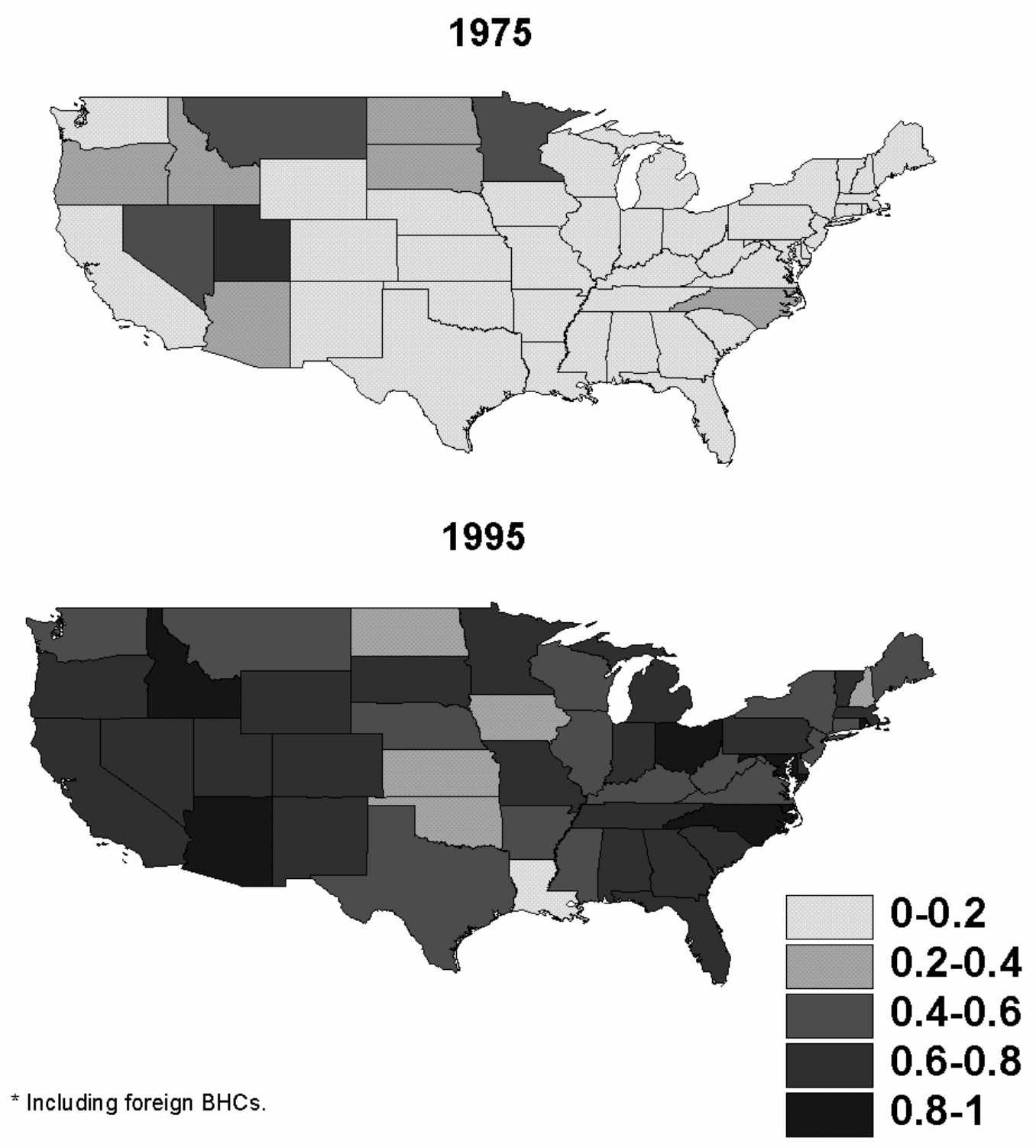


\section{Chart 1: Cross-State Banking Waves}

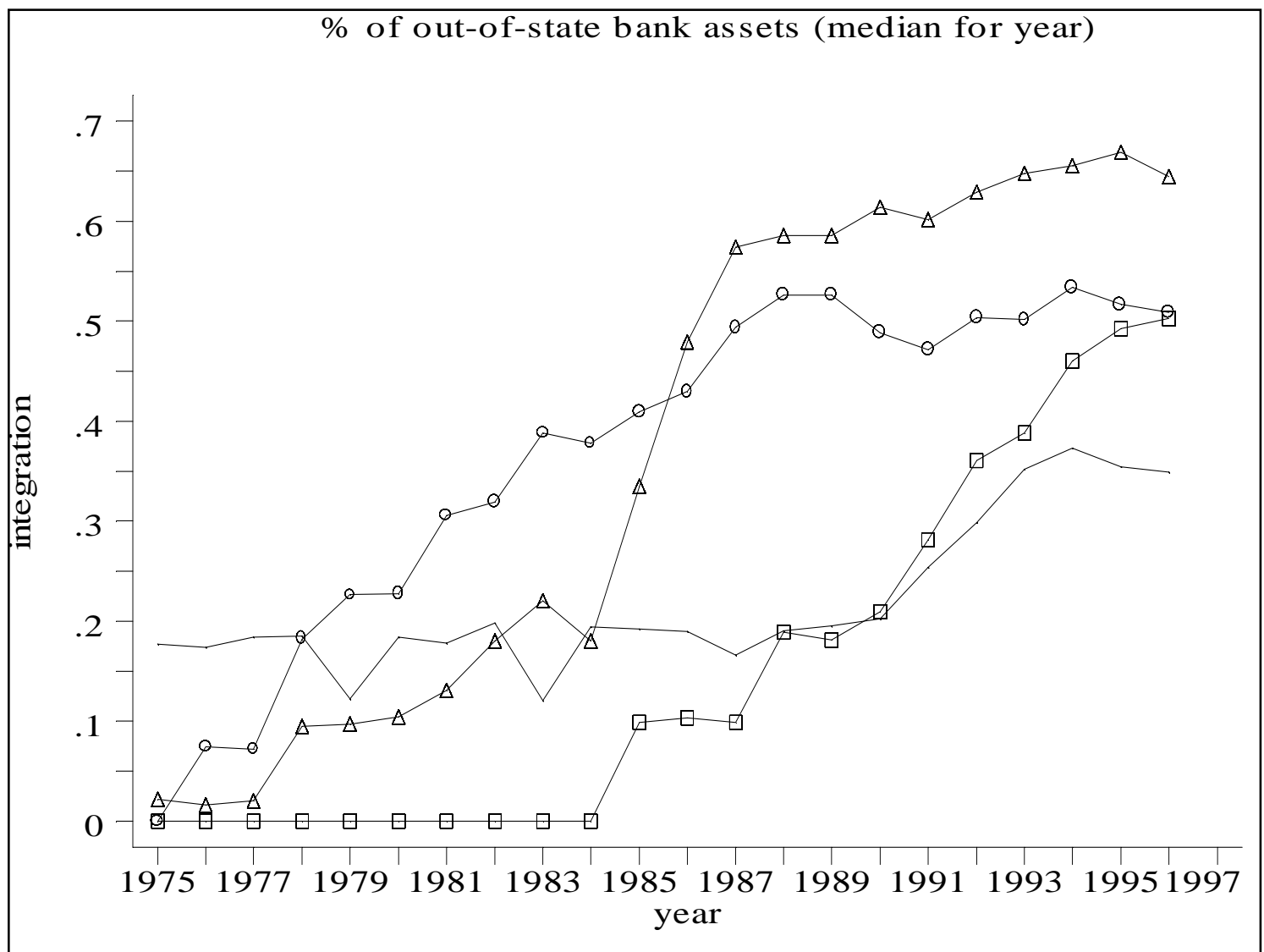

Interstate banking agreements occurred in waves between 1982 and 1993. States were grouped by the year that they entered into an agreement. Plotted for each wave is the median share of out-of-state banking assets for states in each wave.

o: 1982-1984 wave

$\Delta: 1985-1987$ wave

: 1988-1990 wave

_: 1991-1993 wave 


\section{Chart 2:}

The change in bank integration in each state between 1977 and 1993 is not correlated with the change in out-of-state shipments. Note: "Ex-state shipping" = out-of-state shipments/total shipments. Source: Department of Commerce (1977) and Department of Transportation (1993) .

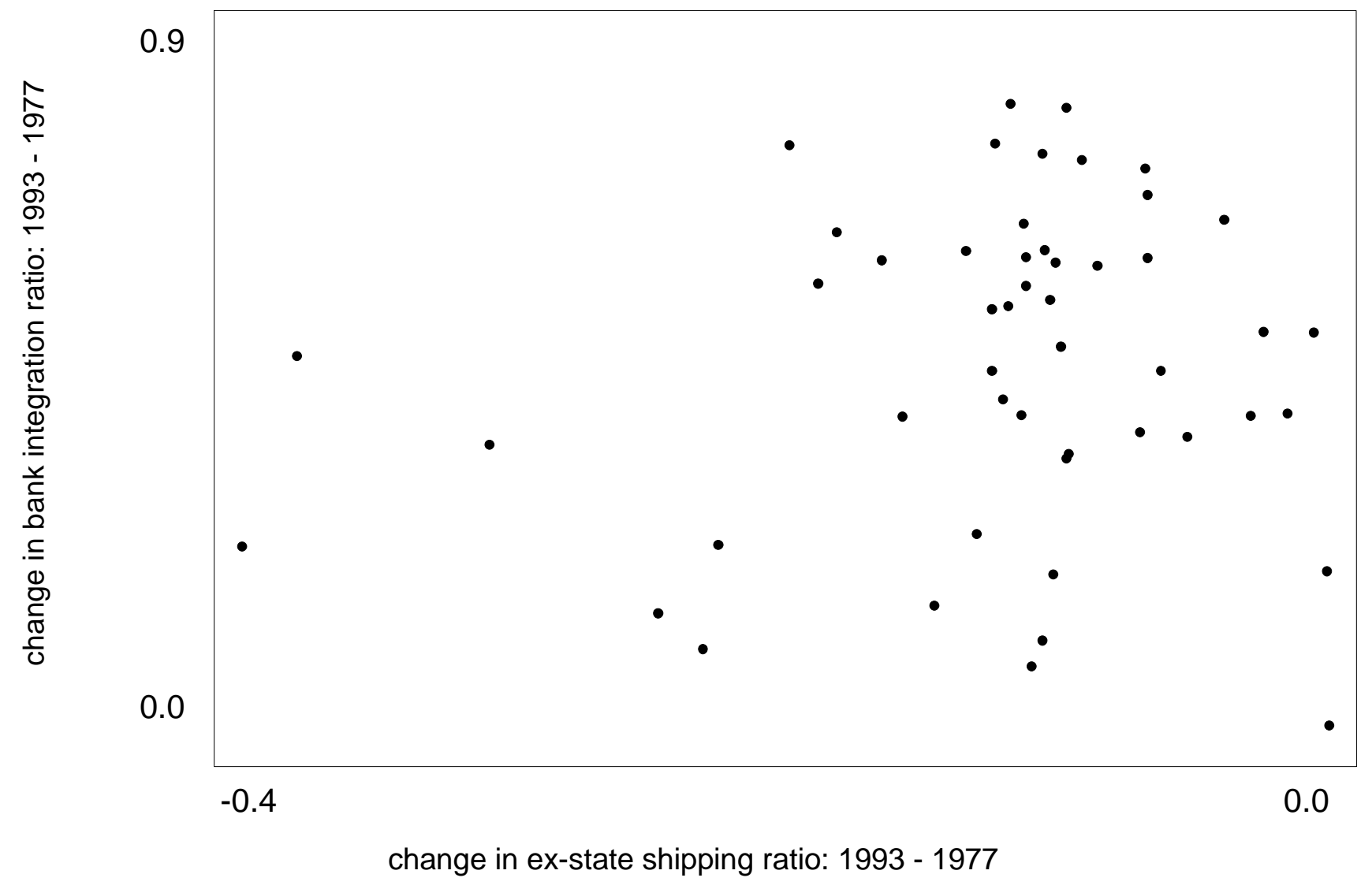

